\title{
Maitohappobakteeriymppien vaikutus esikuivattujen säilörehujen laatuun ja lypsylehmien maidontuotantoon
}

\author{
Eeva Saarisalo $^{1)}$, Seija Jaakkola ${ }^{1)}$, Eija Skyttä ${ }^{2}$ ja Pekka Huhtanen ${ }^{1)}$ \\ ${ }^{1)}$ MTT/Eläinravitsemus, 31600 Jokioinen (etunimi.sukunimi@mtt.fi) \\ ${ }^{2)}$ VTT/Biotekniikka, PL 1500,02044VTT (eija.skytta@vtt.fi)
}

\begin{abstract}
Johdanto
Eri säilöntäaineilla tehtyjen, tuoreiden säilörehujen käymistyypin on todettu vaikuttavan ruuansulatuskanavasta eläimen käyttöön tulevien ravintoaineiden koostumukseen ja sitä kautta tuotantoon ja sen tehokkuuteen. Esikuivatus sinänsä rajoittaa rehussa tapahtuvaa käymistä, joten säilöntäaineiden vaikutukset syöntiin ja eläimen ravintoaineiden saantiin voivat olla erilaiset esikuivatussa ja tuoreessa rehussa.

VTT:n Lactobacillus plantarum VTT E-78076 maitohappobakteerikannan (E76) on todettu mini- ja pilotsiilokokeissa tuottavan homofermetatiivisesti maitohappoa ja näin laskevan nopeasti rehun pH:n säilymisen kannalta riittävän alas. Toisaalta se on myös selvästi vähentänyt ruohon valkuaisen hajoamista ilman säilöntäainetta tehtyyn rehuun verrattuna. Tässä kokeessa tutkittiin ensimmäisen kerran E76 ympin säilöntäkykyä maatilamittakaavassa. Kontrolleina olivat painorehu ja rajoittuneesti käynyt rehu. Vertailussa on mukana myös ensimmäisenä Suomessa myyntiluvan saanut ymppivalmiste. Lypsylehmäkokeessa tutkittiin näiden säilörehujen sekä väkirehun valkuaistasojen vaikutusta esikuivatun rehun syöntiin, sulavuuteen, maidontuotantoon ja ravintoaineiden hyväksikäyttöön.
\end{abstract}

\section{Aineisto ja menetelmät}

Esikuivatut säilörehut tehtiin 20.6.2000 toisen vuoden timotei-nurminatanurmesta. Raaka-aineen kuivaaine oli keskimäärin $366 \mathrm{~g} / \mathrm{kg}$, raaka-valkuainen 109, sokeri 144 ja D-arvo $678 \mathrm{~g} / \mathrm{kg}$ ka. Säilöntäainekäsittelyt olivat: 1) Painorehu (PR) ilman säilöntäainetta, 2) happorehuun (AIV) lisättiin AIV2000 6.1 1/tn, 3) E76-rehuun lisättiin tuoretta, fermentorikasvatettua nesteymppiä 5.1 1/tn ja 4) AIVBioprofitrehuun (BP) kylmäkuivattua ymppiä, käyttöohjeen mukaan laimennettuna 4.9 l/tn. Ymppien annostuksen tavoitteena oli $10^{6} \mathrm{pmy} / \mathrm{g}$. Rehut säilöttiin laakasiiloihin.

Tuotantokoe tehtiin MTT:n Lintupajun lehmänavetassa 10.11 .2000 - 2.2.2001. Koemallina oli cyclic change -over, jossa oli kaksi 8 lehmän blokkia, neljä 21 päivän jaksoa ja 8 ruokintaa. Ruokinnat järjestettiin $2 \times 4$ faktoriaalisesti niin, että valkuaistasoja oli kaksi ja säilörehuja neljä. Väkirehu perustui ohrakaura (50:50) seokseen, jota korvattiin rypsirouheella (rypsi) (VR1: $0 \mathrm{~kg}$ ja VR2: $3 \mathrm{~kg}$ rypsiä/10 kg VR). VR1:n ja VR2:n raakavalkuainen oli 153 ja 238 g/kg ka. VR:a annettiin ensikoille 9 ja muille $10 \mathrm{~kg} / \mathrm{pv}$.

\section{Tulokset}

Säilörehujen käymistyypit vaihtelivat odotetusti. PR:n, AIV-, E76- ja BP-rehujen pH oli 4.41, 4.42, 4.00 ja 4.05, sokeri 83, 172, 80 ja 70, maitohappo 47, 21, 81 ja 74 sekä voihappo 10.6, 0.9, 0.4 ja 2.8 g/kg ka. $\mathrm{NH}_{3}$-typpeä oli 69, 12, $20 \mathrm{ja} 33 \mathrm{~g} / \mathrm{kg} \mathrm{N}$. AIV rehua lehmät söivät ymppirehuja enemmän $(\mathrm{P}<0.01)$, ero ei kuitenkaan näkynyt tuotoksessa. Maitotuotokset (kg/pv) olivat ilman rypsiä 26.5, 26.2, 27.4 ja 25.4 ja rypsin kanssa 28.6, 29.4, 29.6 ja 29.7. Rypsi tasasi erot tuotoksessa, koska sen vaikutus maito- ja EKM tuotokseen oli erilainen E76- ja BP-rehujen kanssa (EKM 2.6 ja $4.5 \mathrm{~kg} / \mathrm{pv}$, yhdysvaikutus $\mathrm{P}<0.05)$. AIVrehun kanssa EKM lisäys oli 4.0 ja painorehun $2.6 \mathrm{~kg} / \mathrm{pv}$. Keskimäärin kilo rypsiä lisäsi maitotuotosta 1.0 $\mathrm{kg}$ ja EKM:a $1.1 \mathrm{~kg} / \mathrm{pv}(\mathrm{P}<0.001)$. Maidon rasvapitoisuus ja -tuotos olivat suurimmat $\mathrm{PR}: 1 \mathrm{la}(\mathrm{P}<0.05)$. Typen hyväksikäytöt (maidon $\mathrm{N}$ /rehun $\mathrm{N}$ ) olivat ilman rypsiä $0.33,0.34,0.36,0.33$ ja rypsin kanssa 0.28 , 0.29, 0.30 ja 0.29 (PR vs säil.aineet ja E76 vs BP, P<0.01).

\section{Johtopäätökset}

Korkeahkosta kuiva-ainepitoisuudesta huolimatta säilöntäaineet paransivat rehun käymislaatua, tosin erot mikrobistossa olivat varsin pieniä. Rehut olivat kuitenkin herkkiä jälkipilaantumiselle säilöntäaineista riippumatta. Esikuivatun rehun kohdalla onkin kiinnitettävä erityistä huomiota rehun tiivistämiseen ja estettävä mahdollisimman tehokkaasti ilman pääsy rehuun myös syöttövaiheessa. Syöttönopeuden pitää myös olla riittävän nopea.

VTT:n L. plantarum E76 tuotti käymislaadultaan hyvää rehua, jonka typen hyväksikäyttö maidontuotannossa oli hyvä. Myös esikuivatun rehun käymistyypillä ja valkuaisen hajoamisasteella on vaikutusta eläimen ravintoaineiden saantiin ja sitä kautta täydennysrehun tarpeeseen. Ilmeisesti rajoittuneesti ja pitkälle käyneiden säilörehujen täydennystarve on erilainen. 